Suwanti and Mufasirin, Afr., J. Infect. Dis. (2018) 12(S): 68-71

https://doi.org/10.2101/Ajid.v12i1S.9

\title{
INCREASED APOPTOSIS SKULL OF PUPS BORN TO TOXOPLASMA GONDII-INFECTED MICE ASSOCIATED WITH INCREASED EXPRESSION OF INTERFERON GAMMA, BUT NOT TUMOR NECROSIS FACTOR ALFA
}

\author{
Lucia Tri Suwanti ${ }^{1,2, *}$ and Mufasirin ${ }^{1,2}$ \\ ${ }^{1}$ Department of Parasitology, Faculty of Veterinary Medicine, Universitas Airlangga, Indonesia; \\ ${ }^{2}$ Institute of Tropical Disease, Universitas Airlangga, Indonesia.
}

*Corresponding Author E-mail: tswant@gmail.com

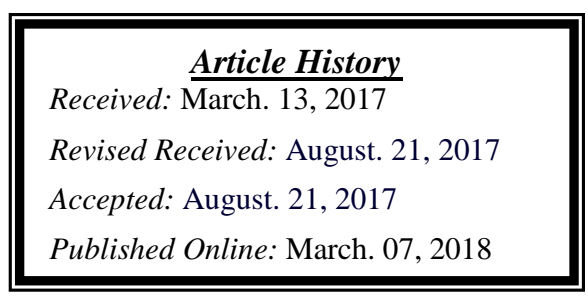

\begin{abstract}
Bacground: Toxoplasma gondii is an intracellular obligate protozoan parasite that infects most warm-blooded animals including humans. It can cause congenital infection with clinical symptoms ranging from mild to severe including microcephaly. At the cellular level, infection $T$. gondii causes apoptosis in some tissues and it is induced by proinflammatory cytokines, such as IFN- $\gamma$ and TNF- $\alpha$. The purpose of this study is to determine the role of proinflammatory cytokines (TNF- $\alpha$ and IFN- $\gamma$ ) to apoptosis skull of newborn from T. gondii-infected mice.

Materials and Methods: Twenty pregnant mice were divided into two groups. The first group was the control group which was not infected with $T$. gondii tachizoites. The second group was the infected mice, which was infected with $T$. gondii tachizoites on the day 11.5 of gestation. All mice were cared until delivery. Subsequenly, pups of the mice were sacrificed and their skullcap tissues were taken for histological preparation. The tissues were stained by TUNEL Assay and IHC. Observed variables were apoptotic index and the percentage of skull cell expressing TNF- $\alpha$ and IFN- $\gamma$. Data were analyzed with t-test and regression.

Results: Compared to the control group, the skull of the pups born to T. gondii-infected mice showed that the number of apoptotic index and percentage of expressing TNF- $\alpha$ and IFN- $\gamma$ cells were higher than the control group. There is no correlation between increasing expression of TNF- $\alpha$ and apoptosis skull of pups. However, an increasing expression of IFN- $\gamma$ affected the increased apoptosis of skull pups born to T.gondii-infected mice.

Conclusion: Congenital toxoplasmosis in mice increased apoptotic index of skull and the apoptosis of skull associated with increasing expression of IFN- $\gamma$, but not associated with increasing expression of TNF- $\alpha$.
\end{abstract}

Keywords: Apoptosis skull, Toxoplasma gondii, proinflammatory cytokines

\section{Introduction}

Apoptosis is a programmed cell death. It occurs normally during development and aging and as a homeostatic mechanism to maintain cell populations in tissues (Elmore, 2007). Apoptosis is also recognized as an important defense system against pathogens during innate and adoptive immune response and may help to eradicate

pathogen from the host (Nishikawa et al., 2007). However in the case of Toxoplasma gondii infection apoptosis occurs in uninfected cells and is induced by soluble factors, such as IFN- $\gamma$ and TNF- $\alpha$ (Nishikawa et al., 2007; Mordue et al., 2001).

T. gondii is an intracellular obligate protozoan parasite. It can infect most species of warm-blooded animals (birds and mammals), including humans that causes congenital infection. Congenital infection occurs predominantly after primary infection of a pregnant female. Clinical symptoms of congenital toxoplasmosis are ranging from mild to severe such as visual impairment, retinochoroiditis, blindness, hydrocephalus or microcephaly, intracarnial calcificasion, seizures, mental retardation, abortion and stillbirth (Sibley et al., 2009; McAuley, 2014). Disorders due to congenital infection are probably related to both cellular and molecular changes in the placenta. T. gondii is known that it has ability to infect all nucleated host-cells and to trigger host-cell apoptosis (Nishikawa et al., 2007). Our previous study showed that pregnant mice infected by T.gondii displayed increased apoptosis of trophoblast and the trophoblasts apoptosis was associated with increased expression of FAS in the trophoblast and IFN- $\gamma$ and TNF- $\alpha$ in decidual cells (Suwanti, 2005). Apoptosis that caused by T. gondii infection also occured in femur bone cells of mice and it was associated with increased TNF- $\alpha$ expression (Suwanti and Mufasirin, 2015). 
In this study, we wanted to determine whether there was increasing bone cell apoptosis index and the role of proinflammatory cytokines (TNF- $\alpha$ and IFN- $\gamma$ ) to apoptosis skull of pups which born to T. gondii-infected mice.

\section{Materials And Methods}

T. gondii, RH strain, was maintained in the intraperioneal of mice. Mice were intraperitoneally infected by $1 \times 10^{6}$ tachyzoites. Four days after infection, mice were sacrificed and their intraperitoneal fluid were collected. The numbers of tachyzoite in intraperitoneal fluid were counted with a haemocytometer.

Forty female mice were mated. Before being mated, the females were weighed. All animals were handled in strict accordance with Ethical Clearance and approved by Ethical Committee, Faculty of Veterinary Medicine, Universitas Airlangga, No: 259-KE. Subsequently, one female and one male were housed in a cage. The next day, mice were evaluated for the presence of a vaginal plug and if it were found positive, mice were estimated already pregnant with 0.5 days gestation age. If there were no vaginal plug, the female was left in the cage with the male and the pressence of a vaginal plug on it as checked every morning. However, the presence of a vaginal plug does not a guarantee of a pregnancy. To ensure that the mice were already pregnant, a week after breeding the mice were weighed. If the weight of the mice increased about 3-4 grams, the mice were certainly pregnant. The pregnant mice were then maintained to 11.5 days of gestational age.

Twenty pregnant mice were divided two groups. The first group was a control group which was not infected with $T$. gondii tachizoites. The second group contained infected mice. In the second group mice were intraperitonally infected with $T$. gondii tachizoites on 11.5 days of gestational age. An infection dose of 10 tachyzoites per mouse was applied. All of mice were cared until delivery. Pups of mice were then sacrificed and their skull tissue were taken for histological preparation. Tissues were fixed in $10 \%$ buffered formalin and embedded in paraffin block.

For detection of apoptosis, tissue was stained by ApopTag ${ }^{\circledR}$ Plus Peroxidase In Situ Apoptosis Detection Kit (Chemicon ${ }^{\circledR}$ International, S7101). The embedding paraffin tissues were cut to sizes of 4-5 micron. Section of each tissue was deparaffinized in xylol and rehydrated in ethanol solution and distilled water. Proteinase $\mathrm{K}$ added to the tissue section for 25 minutes in room temperture and washed with $\mathrm{dH}_{2} \mathrm{O}$. Endogenouse peroxidase activity of tissue was blocked with $\mathrm{H}_{2} \mathrm{O}_{2}$. Subsequently, the tissue was labelled with TdT. TdT labelling was carried out with a commercially available kit and followed the manufacturer's protocol. Finally, the tissue was counterstained by methylene green (Sigma). The value of apoptotic index was the percentage of the positive cells.

Immunohistochemistry for detection of TNF- $\alpha$ and IFN- $\gamma$ was performed with the Dako labeled the streptavidin and biotin kit (Dako A/S, Glostrup, Denmark). Four micron thick tissue sections were deparaffinized, rehydrated and washed with distilled water. Each tissue was divided into two and placed on two separate glass slides, one slide was used to detect TNF- $\alpha$ and the other one was used to detect IFN- $\gamma$. Proteinase K was added to the tissue section for 25 min in room temperature and washed with $\mathrm{dH}_{2} \mathrm{O}$. Endogenouse peroxidase activity of tissue was blocked with $\mathrm{H}_{2} \mathrm{O}_{2}$. Then the tissue was washed twice with PBS. Afterwards the tissue was incubated with an anti TNF- $\alpha$ or IFN- $\gamma$ antibody (Santa Cruz Biotechnology) for $30 \mathrm{~min}$ in a humid chamber at room temperature and washed 3 times with PBS. Following this step, the tissue was carried out with a commercially available kit and followed the manufacturer's protocol. Finally, the tissue was added Haematoxyline as counterstain. To get the value of the percentage cells expressing TNF- $\alpha$ or IFN- $\gamma$, the positive cells divided with all cells in a microscope field and multiplied by one hundred percent.

The data of apoptotic index and the percentage of skull cells expressing TNF- $\alpha$ and IFN- $\gamma$ were analyzed using SPSS version 17. Analytical tests of significance were done using the student t-test and the correlation between apoptotic index and inflamatory cytokine (TNF- $\alpha$ or IFN- $\gamma$ ) were analyzed using linear regression test.

\section{Results}

Overall, the results of calculation and statistical value of the apoptotic index and expression of TNF- $\alpha$ and IFN$\gamma$ of skull of pups of mice was as shown in Tabel 1 and Figure 1-3. The apoptotic index, expression of TNF- $\alpha$ and IFN$\gamma$ of skull of pups born to $T$. gondii-infected mice was higher than the control or uninfected group (p $\leq 0,01$ ). Apoptotic index of skull cells mice on infected group increased about 7 times $(18.46 \%$ in infected group vs $2.77 \%$ in uninfected group), while expresssion of TNF- $\alpha$ and IFN- $\gamma$ of skull of pups born to intected mice increase about 2 times (they are $18.15 \%$ vs $8.48 \%$ for expresssion of TNF- $\alpha$ and $21.19 \%$ vs $8.84 \%$ for expresssion of IFN- $\gamma$ ).

By the regression test, there was not any correlation between increasing expression of TNF- $\alpha$ and apoptosis skull of pups. However, an increased expression of IFN- $\gamma$ affected the increased apoptosis of skull pups born to T.gondii-infected mice. 
Tabel 1: The values of Apoptotic Index, Expression of TNF- $\alpha$ and IFN- $\gamma$ of Skull of Pups

\begin{tabular}{lcccc}
\multicolumn{1}{c}{ Parameters } & Treatment & $\begin{array}{c}\text { Mean number } \\
\text { of cell (\%) }\end{array}$ & $\begin{array}{c}\text { Std. Deviation } \\
(\boldsymbol{\%})\end{array}$ & Significance \\
\hline Apoptotic Index & Uninfected & 2.77 & 0.78 & 0,00 \\
& Infected & 18.46 & 12.07 & \\
Expression of TNF- $\alpha$ & Uninfected & 8.48 & 1.61 & 0,00 \\
& Infected & 18.15 & 7.35 & \\
Expression of IFN- $\gamma$ & Uninfected & 8.84 & 2.52 & 0,00 \\
& Infected & 21.19 & 6.38 & \\
& & & & \\
\hline
\end{tabular}
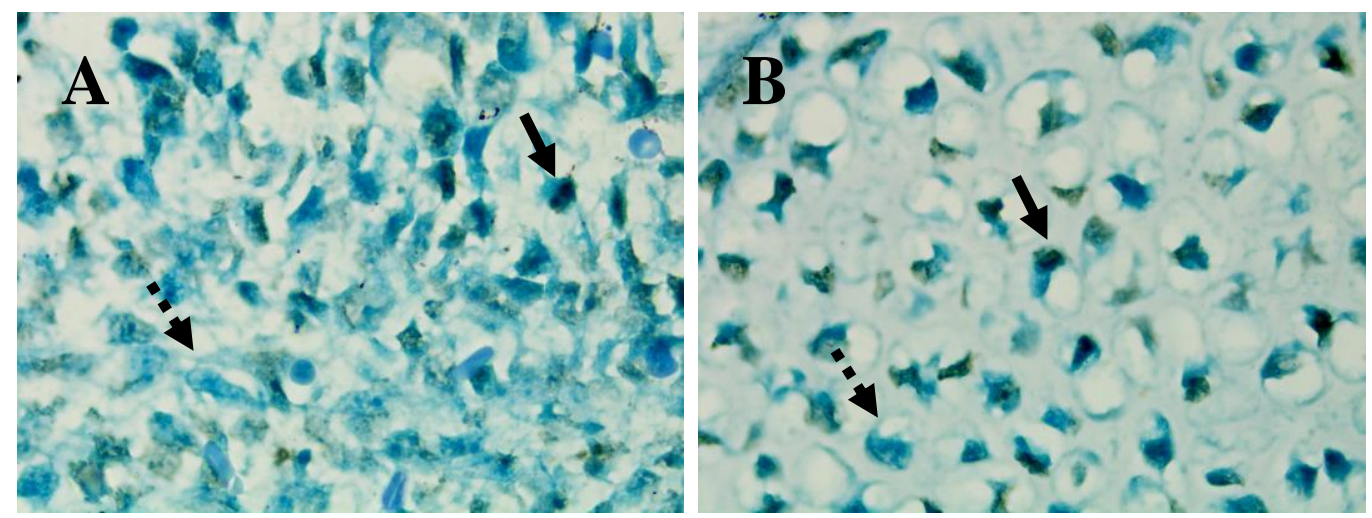

Figure 1: Apoptotic bodies on Mesenchyme (A) and cartilage (B) of skull of congenitally infected mice by TUNNEL staining (P; 1000x). Solid errow: apoptotic bodies . Dash errow: normal cell
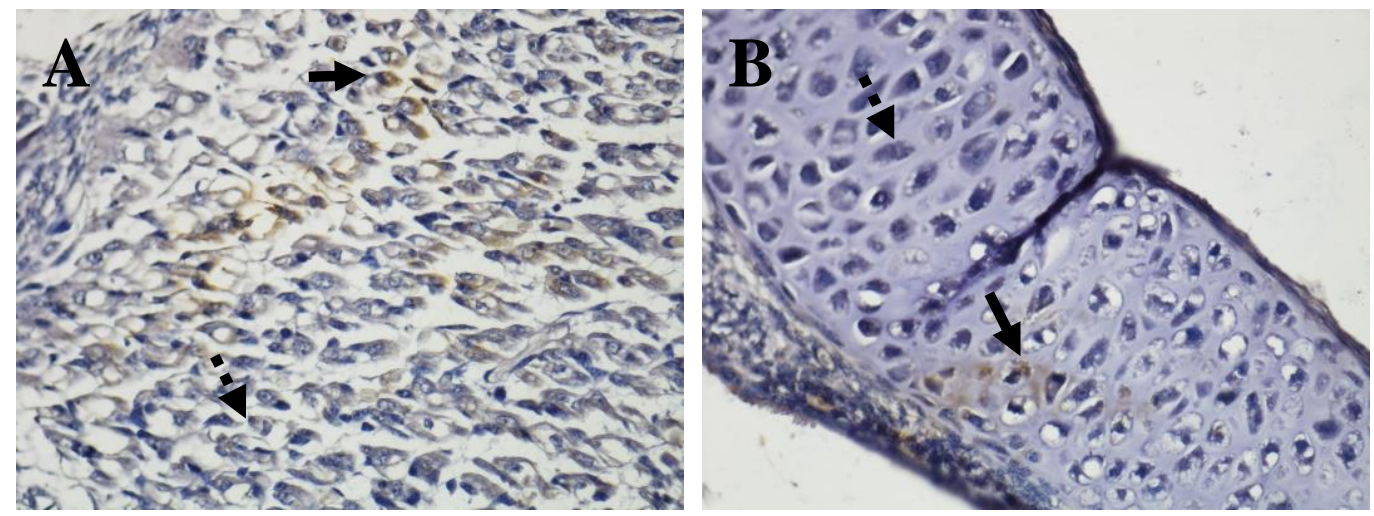

Figure 2: Expression TNF- $\alpha$ on mesenchyme (A) and cartilage (B) of skull of congenitally infected mice. (P400x). Solid errow: positve cells. Dash errow: negative cell

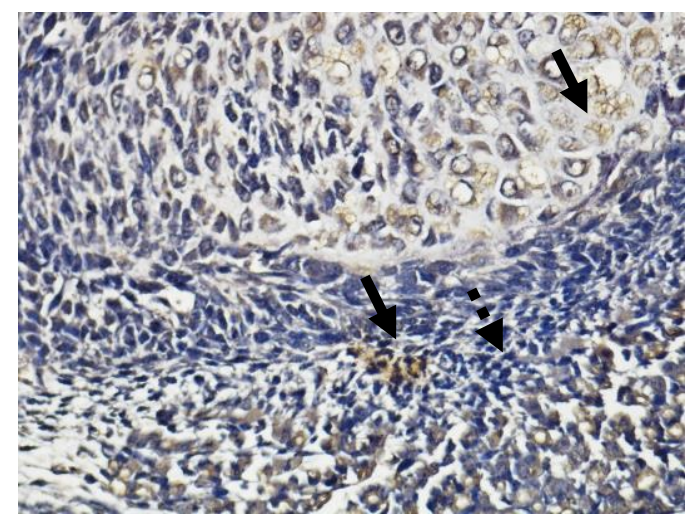

Figure 3: Expression IFN- $\gamma$ on mesenchyme of skull of congenitally infected mice. (P400x). Solid errow: positve cells. Dash errow: negative cell. 


\section{Discussion}

Apoptosis is a physiological cell death that occurs normally during development and aging and as a homeostatic mechanism to maintain cell populations in tissues (Elmore, 2007). However reduced or increased apoptosis from normal may result in a particular pathology (Favaloro et al., 2012). Previous studies showed that acute toxoplasmosis induced apoptosis in liver and spleen (Mordue et al., 2001), trophoblast (Suwanti et al, 2006) or femur (Suwanti and Mufasirin 2015). On the other hand, accoding to Mordue et al (2001) and Nishikawa et al (2007), apoptosis in toxoplasmosis occurs in noninfected cells. In this study, it was found that during congenital toxoplasmosis also induced apoptosis of bone cell of skull. The data in this research clearly demonstrate that there were an increased apoptosis in the skull of pups born to T.gondii- infected mice. This might be an explanation of cases of microcephaly in toxoplasmosis congenital.

Toxoplasma gondii infection induced expression of TNF- $\alpha$ and IFN- $\gamma$. Those cytokine were important for controlling tachyzoite replication during both acute and chronic phases of infection (Denkers and Gazzinelli, 1998). In this study, it showed that congenitally T. gondii infection induced increased expression of TNF- $\alpha$ and IFN- $\gamma$ in the skull of pups. This discovery completed our previous studies that also showed that $T$. gondii infection increased expression of TNF- $\alpha$ and IFN- $\gamma$ (Suwanti, 2006; Suwanti, 2008; Suwanti and Mufasirin, 2015).

TNF- $\alpha$ and IFN- $\gamma$ were cytokine proinflamtion, and thus over expression of IFN- $\gamma$ could caused extensive damage in many organ by triggered apoptosis (Gavrilescu and Denkers, 2001; Mordue et al., 2001). In this study, by the regression test, we found that cytokine IFN- $\gamma$ induced apoptosis the skull cell of pups. There is no explanation as to why TNF $-\alpha$ was not associated with apoptosis in this cases, so further research is needed to reveal it. According to Baxer et al. (1999), TNF- $\alpha$ has two action, to induce apoptosis and to stimulate cellular proliferation.

\section{Conclusion}

This study revealed that congenital toxoplasmosis caused an increased apoptosis of the skull of pups and cytokine proinflamatory, TNF- $\alpha$ and IFN- $\gamma$. In case of congenital toxoplasmosis, increased apoptosis of the skull of pups associated with an increased expresion of IFN- $\gamma$, but not with an increased expresion of TNF- $\alpha$.

Statement on Conflict of Interest: There was not any conflicting interest among authors.

Acknowledgements: We would like to thank The Indonesian Directorate of Higher Education for supporting funds by a grand of Flagship Research Universities.

\section{References}

1. Baxer, G.T., Kuo, R.C., Jupp, O.J. and MacEwan, D.J. (1999). Tumor Necrosis Factor- $\alpha$ Mediates Both Apoptotic Cell Death and Cell Proliferation in a Human Hematopoietic Cell Line Dependent on Mitotic Activity and Receptor Subtype Expression. Journal of Biology Chemistry, 274 (14):9539-9547

2. Denkers, E.Y. and Gazzinelli, R.T. (1998). Regulation and function of T-cell-mediated immunity during Toxoplasma gondii infection. Clinical Microbiology Reviews, 11(4): 569-588

3. Favaloro B, Allocati, N., Graziano, V., Di Ilio, C. and De Laurenzi, V. (2012) Role of Apoptosis in disease. Aging 4 (5): 330-349

4. Gavrilescu, L.C. and Denkers, E.Y. (2001). IFN- $\gamma$ overproduction and highlevel apoptosis are associated with high but not low virulence Toxoplasma gondiiinfection. Journal of Immunology, 167: 902-909

5. Elmore, S. (2007). Apoptosis: A Review of Programmed Cell Death. Toxicologic Pathology, 35(4): $495-516$

6. Nishikawa, Y., Kawase, O., Vielemeyer, O., Suzuki, H., Joiner, K.A., Xuan, X. and Nagasawa, H. (2007). Toxoplasma gondii infection induces apoptosis in noninfected macrophages: role of nitric oxide and other soluble factors. Parasite Immunology, 29: 375-385

7. McAuley, J.B. (2014). Congenital Toxoplasmosis. Journal of Pedatric Infectious Disease Society, 3(suppl 1): S30-S35.

8. Mordue, D.G., Monroy, F., La Regina, M., Dinarello, C.A. and Sibley, L.D. (2001). Acute toxoplasmosis leads to lethal overproduction of Th1cytokines. Journal of Immunology, 167: $4574-4584$.

9. Sibley, L.D., Khan, A., Ajioka, J.W. and Rosenthal, B.M. (2009). Genetic diversity of Toxoplasma gondii in animals and humans. Philosophical Transactions of the Royal Society Biological Science, 364(1530): 2749-2761

10. Suwanti, L.T. (2005). Mekanisme Peningkatan Apoptosis Trofoblas Mencit Terinfeksi Toxoplasma gondii melalui Peningkatan Desidua Penghasil IFN- dan TNF- serta Trofoblas Penghasil FAS dan TNFR-1. Disertasi Program Pascasarjana Universitas Airlangga. Surabaya.

11. Suwanti, L.T. (2006). Respons Imun Seluler Plasenta terhadap Infeksi Toxoplasma gondii pada Berbagai Umur Kebuntingan Mencit (Mus musculus). Media Kedokteran Hewan, 22(3):168-173

12. Suwanti, L.T. (2008). Peningkatan aktivitas Makrofag Desidua Mencit Bunting Yang diinfeksi Toxoplasma gondii. Media Kedokteran Hewan, 24(1): 63-67

13. Suwanti, L.T. dan Mufasirin. (2015). Peran TNF- $\alpha$ pada Apoptosis Tulang Mencit yang Diinfeksi Toxoplasma gondii. Jurnal Kedokteran Hewan, 9(2): $101-104$

14. Suwanti, L.T., Sasmita, R. and Putra, S.T. (2006). Toxoplasma gondii Infection Elicits The Increase of Fas Expression on The Trophoblast Associated with The Increase of Trophoblast Apoptosis. Folia Medica Indonesiana, 42(1): 3-7. 